\title{
EKONOMI KREATIF, UPAYA MENINGKATKAN EKONOMI MASYARAKAT DESA DAN MENGURANGI DAMPAK LIMBAH PLASTIK
}

\author{
Dadang Amiruddin \\ Universitas Banten Jaya, Jl Syech Nawawi Albantani Serang, Banten, Indonesia \\ Email: dadang.amiruddin@gmail.com
}

\begin{abstract}
The aim of Kuliah Kerja Mahasiswa (KKM) Banten Jaya University (Unbaja) 2019 are improves the skills and creativity of the society of Cikolelet, specifically for women / housewives. The problem that is being face at the moment is that people don't understand how to utilizing used plastic drink waste that can have economic value. The method of implementing this program is (1) field monitoring, interviews, and exploring potentials, (2) providing handicraft training from waste materials used in plastic beverage glass lid (3) providing knowledge on how to do online marketing of handicraft products. The result of this program is that the society of Cikolelet have the skills and creativity in managing plastic waste that can have economic value. With this program it is hoped that the society of Cikolelet can improve their creativity so that they can support Cikolelet as a Tourism Village.
\end{abstract}

Keywords: Crafts; Plastic Waste.

\begin{abstract}
ABSTRAK
Program Kuliah Kerja Mahasiswa (KKM) Universitas Banten Jaya (Unbaja) 2019 bertujuan meningkatkan keterampilan dan kreatifitas masyarakat desa Cikolelet, kecamatan Cinangka, kabupaten Serang, khususnya kaum perempuan/ibu rumah tangga. Permasalahan yang dihadapi saat ini adalah kurangnya pemahaman masyarakat desa dalam memanfaat limbah bekas tutup minuman gelas berbahan plastik yang dapat memiliki nilai ekonomi. Metode pelaksanaan program ini adalah (1) pengamatan lapangan, wawancara, dan menggali potensi, (2) memberikan pelatihan kerajinan tangan dari bahan limbah bekas tutup minuman gelas berbahan plastik (3) memberikan pengetahuan cara melakukan pemasaran secara online hasil kerajinan tangan. Hasil dari program ini adalah masyarakat desa cikolelet memiliki keterampilan dan kreatifitas dalam mengelola limbah plastik yang dapat memiliki nilai ekonomi. Dengan adanya program ini diharapkan masyarakat Desa Cikolelet dapat meningkatkan kreatifitasnya sehingga dapat menunjang Desa Cikolelet sebagai Desa Wisata.
\end{abstract}

Kata Kunci: Kerajinan Tangan; Limbah Plastik.

\section{PENDAHULUAN}

Limbah adalah buangan yang dihasilkan dari suatu proses produksi baik industri maupun domestik (rumah tangga). Di mana masyarakat bermukim, di sanalah berbagai jenis limbah akan 
dihasilkan. Ada sampah, ada air kakus (black water), dan ada air buangan dari berbagai aktivitas domestik lainnya (grey water). Limbah padat lebih dikenal sebagai sampah, yang seringkali tidak dikehendaki kehadirannya karena tidak memiliki nilai ekonomis. Bila ditinjau secara kimiawi, limbah ini terdiri dari bahan kimia Senyawa organik dan Senyawa anorganik. Dengan konsentrasi dan kuantitas tertentu, kehadiran limbah dapat berdampak negatif terhadap lingkungan terutama bagi kesehatan manusia, sehingga perlu dilakukan penanganan terhadap limbah. Tingkat bahaya keracunan yang ditimbulkan oleh limbah tergantung pada jenis dan karakteristik limbah.

Salah satu limbah padat adalah sampah plastik. Setiap hari manusia di muka Bumi ini menggunakan plastik untuk berbagai kebutuhan, seperti sebagai kantong makanan, belanja, media untuk membungkus, alat-alat rumah tangga, dan lain-lain. Ketika plastik tersebut sudah tidak digunakan lagi, apakah plastik tersebut hilang? Tentu tidak. Sampah plastik seperti bungkus detergen, dll memerlukan waktu 50 - 80 tahun untuk dapat terurai atau hancur, sedangkan kantung plastik (tas kresek) diperlukan waktu 10 hingga 20 tahun untuk hancur. Salah satu upaya yang dilakukan untuk mengurangi sampah plastik adalah dengan melakukan daur ulang sampah plastik. Data Sustainable Waste Indonesia (SWI), kurang dari 10\% sampah plastik terdaur ulang dan lebih $50 \%$ tetap berakhir di tempat pembuangan akhir (TPA).

Sejak resmi ditetapkan sebagai desa wisata oleh Bupati Serang Ratu Tatu Chasanah pada tahun 2018, desa Cikolelet selalu ramai dikunjungi oleh wisatawan. Berdasarkan informasi dari Pemerintah Desa Cikolelet, tercatat sebanyak 3 ribu wisatawan berkunjung ke beberapa obyek wisata di desa Cikolelet, seperti Puncak Cibaja dan Puncak Pilar selama libur Lebaran 2019. Jumlah kunjungan wisatawan ke desa Cikolelet selalu meningkat dari waktu ke waktu. Hal ini dapat berpotensi menghasilkan sampah plastik dalam jumlah yang terus meningkat dari waktu ke waktu. Oleh karena itu, kegiatan KKM Unbaja 2019 bertujuan meningkatkan keterampilan dan kreatifitas serta memberdayakan masyarakat desa Cikolelet kecamatan Cinangka kabupaten Serang, khususnya kaum perempuan dalam mengelola limbah bekas tutup minuman gelas berbahan plastik menjadi produk yang bermanfaat dan memiliki nilai jual.

\section{METODE}

Metode yang digunakan dalam menjalankan program ini adalah (1) Pembekalan kepada mahasiswa pendamping lapangan dengan instruktur ibu $\mathrm{Hj}$. Andi Halijah dari "Luluana Handycraft" sebagai salah satu pelaku ekonomi kreatif yang telah berpengalaman dalam membuat kerajinan tangan berbahan bekas tutup gelas plastik dan produknya sering dipamerkan dalam beberapa event, baik regional maupun nasional. (2) Pelatihan kepada masyarakat desa 
Cikolelet yang diawali dengan penjelasan mengenai dampak dari limbah berbahan plastik serta bagaimana mengelola limbah berbahan plastik agar dapat menghasilkan suatu produk yang memiliki nilai jual. (3) Demonstrasi cara pembuatan tas jinjing berbahan limbah bekas tutup minuman gelas berbahan plastik yang dilakukan oleh mahasiswa pendamping. (4) Praktek pembuatan tas jinjing dengan bimbingan Dosen Pembimbing Lapangan dan mahasiswa pendamping.

\section{Alat dan Bahan}

Untuk dapat menghasilkan 1 buah tas jinjing dengan kapasitas 7,5 L yang berbahan limbah bekas tutup minuman gelas berbahan plastik, diperlukan beberapa alat dan bahan sebagai berikut :

a. Alat

Alat yang diperlukan adalah gunting dan cutter yang digunakan untuk memotong dan membersihkan bahan.

b. Bahan

Bahan yang diperlukan untuk membuat produk adalah limbah bekas tutup minuman gelas berbahan plastik, tali plastik ukuran kecil dan sedang, dan selang elastis ukuran 3/8 inch.

\section{c. Cara Kerja}

1) Persiapan bahan

Potong bagian atas bekas minuman gelas berbahan plastik dan bersihkan dari kotoran yang melekat. Bersihkan dan rapihkan hasil potongan tersebut dengan menggunakan cutter sehingga membentuk lingkaran (gelang). Dibutuhkan sebanyak 150 buah bekas tutup minuman gelas, otongan tali plastik ukuran kecil dengan panjang \pm 2 meter sebanyak 7 buah, potongan tali plastik ukuran sedang dengan panjang $\pm 70 \mathrm{~cm}$ sebanyak 2 buah, dan potongan selang elastis ukuran $3 / 8$ inch sepanjang $50 \mathrm{~cm}$.

2) Pembuatan rangkaian dasar tas

Pertama, membuat rangkaian dasar samping tas. Rangkaikan sebanyak 5 gelang dengan saling mengikat antara gelang yang satu dengan gelang yang lainnya, kemudian ikat antar gelang dengan menggunakan tali ukuran kecil sebagai dasar rangkaian. Rangkaiankan gelang yang lainnya dan ikat dengan tali yang mengikat pada 5 gelang sebagai rangkaikan awal. Rangkaikan gelang sebanyak 42 buah sampai membentuk lingkaran. Buatlah sebanyak 3 rangkaian dasar samping tas. Kedua, membuat rangkaian dasar bawah tas. Sama caranya dengan membuat rangkaian dasar samping tas, namun jumlah gelang yang dirangkaikan adalah 12 gelang. Buatlah sebanyak 2 buah rangkaian dasar bawah tas. 
3) Pembuatan tas jinjing

Pertama, rangkaikan ketiga rangkaian dasar samping tas yang telah dibuat menjadi satu sehingga membentuk satu lingkaran. Pergunakan tali ukuran kecil untuk menyatukan ketiga rangkaian dasar samping tas. Kedua, satukan rangkaian dasar bawah secara berdampingan, gunakan tali kecil untuk mengikatnya menjadi satu. Ketiga, gabungkan rangkaian dasar samping dan dasar bawah sehingga membentuk seperti wadah. Pergunakan tali kecil untuk mengikat rangkaian dasar samping dan bawah tas. Keempat, membuat pegangan tas. Masukan tali ukuran sedang ke dalam selang elastis. Sisipkan selang yang sudah dimasukan tali plastik pada kedua sisi rangkaian dasar bagian atas dan gunakan tali ukuran kecil sebagai pengikat.

\section{HASIL DAN PEMBAHASAN}

\section{Pembekalan kepada mahasiswa pendamping lapangan.}

Kegiatan awal yang dilakukan adalah mengadakan pembekalan kepada mahasiswa pendamping lapangan melalui workshop. yang diberikan oleh instruktur dari "Luluana handycraft", ibu Hj. Andi Halijah. Workshop diawali dengan persiapan alat dan bahan yang dibutuhkan. Workshop dilanjutkan dengan membuat rangkaian dasar samping dan bawah tas. Masing-masing peserta ditugaskan untuk membuat rangkaian dasar samping tas sesuai dengan arahan instruktur, dilanjutkan dengan membuat rangkaian dasar bawah tas. Kemudian menggabungkan rangkaian dasar samping dan bawah sehingga membentuk tas. Terakhir, peserta membuat pengait tas yang dibuat dari selang plastik yang disisipkan tali ukuran sedang.
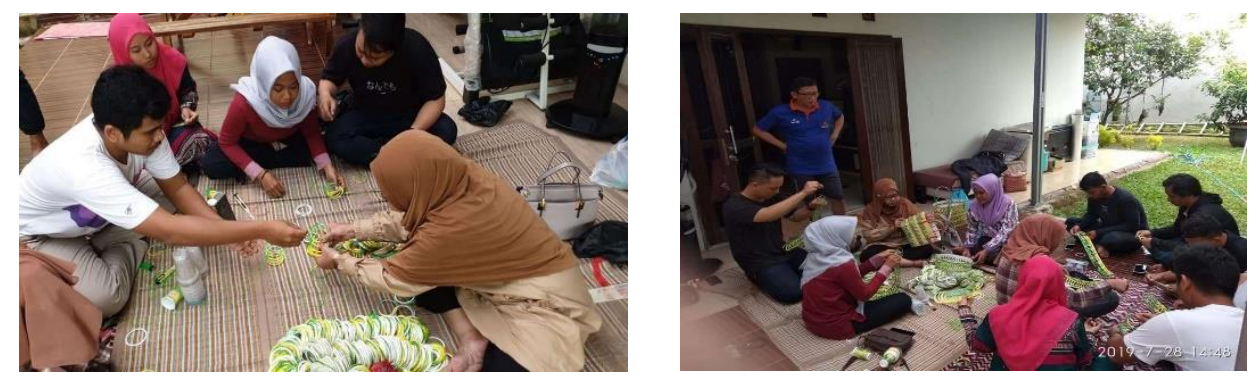

Gambar 1. Kegiatan Pembekalan Mahasiswa Pendamping 
Kegiatan ini dilaksanakan pada hari Minggu, 28 Juli 2019 bertempat di kediamanm

Dosen Pembimbing Lapangan. Kegiatan berlangsung mulai pukul 13.00 - 19.30.

2. Pelaksanaan Pelatihan: pemberian materi dampak dari limbah berbahan plastik dan Pembuatan Tas Jinjing.

Kegiatan pelatihan dilaksanakan pada tanggal 18 - 23 Agustus 2019, bertempat di kediaman Kepala Desa Cikolelet.
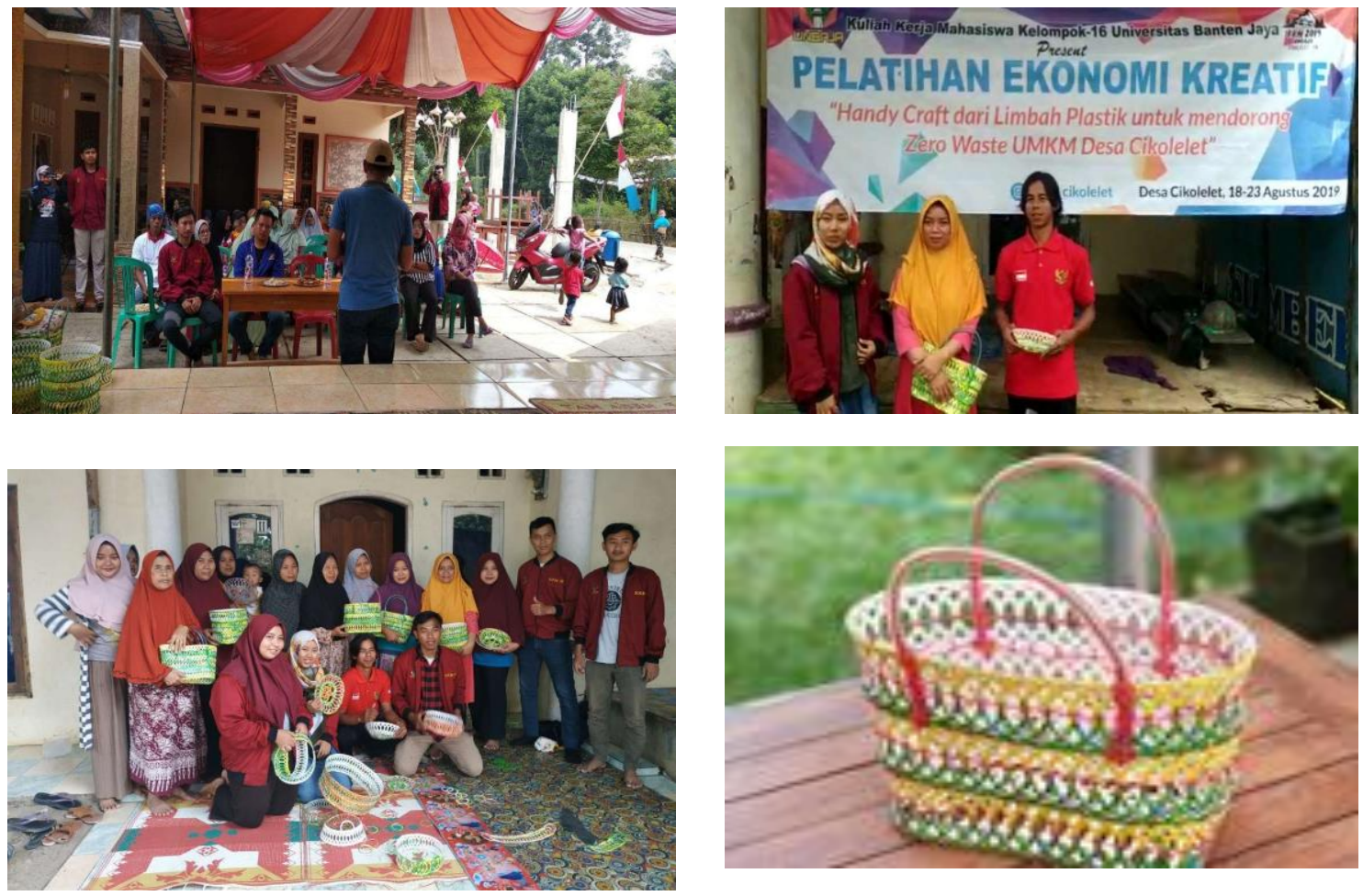

\section{Gambar 2. Pelatihan Pemanfaatan Limbah Bekas Tutup Minuman Gelas Berbahan Plastik dan Hasil Pelatihan}

Pelaksanaan pelatihan ini mendapatkan respon yang sangat baik dari masyarakat desa cikolelet. Pada hari pertama pembukaan kegiatan ini dihadiri olelh 27 orang warga desa Cikolelet. Antusias warga terlihat ketika proses pelatihan dimulai, dimana banyak warga yang ingin mengetahui lebih lanjut tentang cara pembuatan kerajinan ini. Pada hari berikutnya, masih banyak warga yang antusias untuk mengikuti pelatihan ini. Bahkan warga yang sudah lansia pun ikut serta dalam pelatihan kerajinan tangan ini. Pada hari ketiga pelatihan sudah terdapat beberapa warga yang sudah dapat membuat tas jinjing dan ada warga yang berkreasi sendiri dengan membuat produk selain tas jinjing. Disamping itu pula, peserta pelatihan diberikan informasi bagaimana melakukan pemasaran produk secara online dengan memanfaatkan internet 
sebagai media online.

\section{KESIMPULAN}

Setelah dilakukan kegiatan Kuliah Kerja Mahasiswa (KKM) Unbaja 2019 dengan tema "Ekonomi Kreatif, Upaya Meningkatkan Ekonomi Masyarakat Desa dan Mengurangi Dampak Limbah Plastik (Pemanfaatan Limbah Bekas Tutup Minuman Gelas Berbahan Plastik di Desa Cikolelet, Kecamatan Cinangka, Kabupaten Serang)", terjadi peningkatan keterampilan masyarakat desa Cikolelet dalam memanfaatkan limbah bekas tutup minuman gelas berbahan plastik yang selama ini menumpuk ditempat pembuangan sampah dan tidak memiliki nilai ekonomi. Disamping itu pula timbulnya kreatifitas masyarakat desa Cikolelet dalam memanfaatkan limbah tersebut untuk merubahnya menjadi suatu produk yang memiliki nilai jual, yang secara tidak langsung menjadikan masyarakat desa Cikolelet yang produktif dan kreatif dalam mendukung Cikolelet sebagai Desa Wisata.

\section{UCAPAN TERIMA KASIH}

Ucapan terima kasih disampaikan kepada:

1. Kepala Desa Cikolelet, bapak Ojat Darojat yang telah memberikan kesempatan kepada kami untuk melakukan KKM di desa Cikolelet.

2. Mahasiswa KKM Unbaja 2019, khususnya kelompok 16 yang telah menjalankan program kerjanya dengan baik.

\section{DAFTAR PUSTAKA}

Cikolelet, Cinangka, Serang https://id.wikipedia.org/wiki/Cikolelet,_Cinangka,_Serang. Diakses tanggal 14 September 2019.

Definisi Limbah https://id.wikipedia.org/wiki/Limbah. Diakses tanggal 14 September 2019.

Hindari Budaya Nyampah https://www.p-wec.org/id/go-green/hindari-budaya-nyampah. Diakses tanggal 14 September 2019Daur ulang sampah plastik https://www.mongabay.co.id/2019 /09/10/daur-ulang-sampah-plastik-di-indonesia-rendah/ Diakses tanggal 14 September 2019. 